\title{
Mask Use pattern, Public Perception and Barriers to Effective Mask Usage-A battle far from over
}

Sarit Sharma ${ }^{1}$, Bishav Mohan ${ }^{2}$, Pranjl Sharma ${ }^{3}$, Rakesh Agrawal ${ }^{4}$, Jayabalan Elanchezhian ${ }^{5}$, Rupinder Kaur Sran ${ }^{6}$, Anurag Chaudhary ${ }^{7}$, Sangeeta Girdhar ${ }^{8}$, Mahesh Satija ${ }^{9}$, Vikram Kumar Gupta ${ }^{10}$, Priya Bansal ${ }^{11}$, Surinder Pal Singh $^{12}$, Hitesh Verma ${ }^{13}$, Hirdayjit Singh ${ }^{14}$, Archit Pal Singh ${ }^{15}$

${ }^{1}$ Professor, Department of Community Medicine, Dayanand Medical College \& Hospital, Ludhiana, Punjab; ${ }^{2}$ Professor, Department of Cardiology, Dayanand Medical College \& Hospital, Ludhiana, Punjab; ${ }^{3}$ Assistant Professor, Department of Community Medicine, Dayanand Medical College \& Hospital, Ludhiana, Punjab; ${ }^{4}$ Commissioner of Police, Ludhiana, Punjab; ${ }^{5} J o i n t$ Commissioner of Police, Ludhiana, Punjab; ${ }^{6}$ Additional Deputy Commissioner of Police, Ludhiana, Punjab; ${ }^{7}$ Professor \& Head, Department of Community Medicine, Dayanand Medical College \& Hospital, Ludhiana, Punjab; ${ }^{8}$ Professor, Department of Community Medicine, Dayanand Medical College \& Hospital, Ludhiana, Punjab; ${ }^{9}$ Professor, Department of Community Medicine, Dayanand Medical College \& Hospital, Ludhiana, Punjab; ${ }^{10}$ Associate Professor, Department of Community Medicine, Dayanand Medical College \& Hospital, Ludhiana, Punjab; ${ }^{11}$ Associate Professor, Department of Community Medicine, Dayanand Medical College \& Hospital, Ludhiana, Punjab; ${ }^{12}$ Associate Professor, Department of Community Medicine, Dayanand Medical College \& Hospital, Ludhiana, Punjab; ${ }^{13}$ MBBS Intern, Dayanand Medical College \& Hospital, Ludhiana, Punjab; ${ }^{14} \mathrm{MBBS}$ Intern, Dayanand Medical College \& Hospital, Ludhiana, Punjab; ${ }^{15} \mathrm{MBBS}$ Intern, Dayanand Medical College \& Hospital, Ludhiana, Punjab.

\begin{tabular}{|c|c|c|c|c|c|c|c|c|}
\hline \multirow{2}{*}{\multicolumn{2}{|c|}{\begin{tabular}{|c|c|} 
Abstract & Introduction \\
Corresponding Author
\end{tabular}}} & lethodology & Results & Conclusion & $\underline{\text { References }}$ & Citation & \multicolumn{2}{|c|}{ Tables / Figures } \\
\hline & & & & & & & & \\
\hline \multicolumn{8}{|c|}{$\begin{array}{l}\text { Dr. Sarit Sharma, Professor, Dept. of Community Medicine, Dayanand Medical College and Hospital, College } \\
\text { Campus, Civil Lines, Ludhiana-141001, INDIA } \\
\text { E Mail ID: saritsharmadr@gmail.com }\end{array}$} & 口iritis \\
\hline
\end{tabular}

\section{Citation}

Sharma S, Mohan B, Sharma P, Agrawal R, Elanchezhian J, Sran RK, Chaudhary A, Girdhar S, Satija M, Gupta VK, Bansal P, Singh SP, Verma H, Singh H, Singh AP. Mask Use pattern, Public Perception and Barriers to Effective Mask Usage-A battle far from over. Indian J Comm Health. 2021;33(2):329-336. https://doi.org/10.47203/IJCH.2021.v33i02.019

Source of Funding: Nil Conflict of Interest: None declared

\section{Article Cycle}

Received: 01/06/2021; Revision: 09/06/2021; Accepted:24/06/2021; Published:30/06/2021

This work is licensed under a Creative Commons Attribution 4.0 International License.

\section{Abstract}

Background \& Objective: Proper mask wearing reduces the transmissibility and risk of Covid-19 infection still compliance to mask use is low. This study was conducted to observe the mask usage pattern, perception and barriers to effective mask usage (EMU). Settings and Design: This cross-sectional study was conducted in collaboration with district police administration to observe mask usage pattern in various crowded places. Methods and Material: Participants from general public $(n=6995)$ in 10 preselected areas of city were observed and then interviewed about their perceptions about EMU. Indirect observation of EMU was also done by screening CCTV footage, followed by another set of observation at same places after conducting a health education campaign. Data was entered in Microsoft excel and analyzed using SPSS. P value $<0.05$ was considered significant. Results: EMU was seen in nearly $62 \%$ participants. Younger age, native population, education above matric, persons driving two \& four wheelers, had significantly higher compliance. During CCTV observation, EMU was $57.5 \%$, and was highest near public places, roads and intersections while lowest near bus stand and religious places. Some improvement in compliance was seen after health education at these places. Breathing difficulty, no use of wearing mask and feeling uncomfortable were the most common reasons given by participants for non-compliance.Conclusions: EMU was lower in elderly, migrants, less educated, unemployed, daily wage workers, so these groups should be especially sensitized about preventive measures. There is need for extensive public education to bring out behavioral change regarding proper mask wearing to control this pandemic and prevent further waves.

\section{Keywords}

Covid-19; Compliance; Effective mask usage; Health education; Perceptions 


\section{Introduction}

COVID-19 pandemic is not showing signs of abating in near future. USA, India and Brazil are topping the list in total number of infected cases till now. Worldwide, approximately 170 million people have been infected with COVID-19 virus and more than 3.5 million deaths have been reported till $30^{\text {th }}$ May 2021 and the number is still rising.(1) In India, there were approx. 27.9 million infected cases and 329,014 deaths from Covid-19 as reported on $30^{\text {th }}$ May, 2021.(2) The world has again entered into resurgence of pandemic in many countries.(3) The cause of second, third wave can't be ascertained precisely but epidemiologists are attributing it to decreasing compliance to prevention strategies such as mask usage and social distancing after the first wave of COVID pandemic started receding. Some studies attribute it to more infectious mutant strains of virus. $(4,5)$

Earlier in year 2020, number of new infected cases per day peaked in mid-September to approximately 97,859 in India, followed afterwards by a declining trend with lowest number of new infections being 8587 per day on $1^{\text {st }}$ Feb,2021 which is the lowest till now. New cases started increasing exponentially in March and April with the highest spike of 414,433 on $6^{\text {th }}$ May and this peak is higher than the previous one in mid-September.(6) Maharashtra, Karnataka, Kerala, and Punjab were some of the most affected states in terms of total number of new cases and fatalities across the country.(7)In Punjab, Ludhiana is one of the most affected district and is reemerging as the COVID capital of Punjab.(8,9)

Ludhiana district administration had made mask wearing mandatory for everyone in public places, but the compliance to proper mask wearing was low. So, this community-based study was planned to observe the existing mask usage pattern as well as the perception of general public about mask usage so that suggestions can be provided to increase the compliance to effective mask usage.

\section{Aims \& Objectives}

1. To know the prevalence, pattern and perceptions about effective mask usage in study population

2. To elicit the barriers to effective mask usage in the participants

\section{Material \& Methods}

Study design: This analytical cross-sectional study was conducted in Ludhiana city after approval from Institutional Ethics Committee and was carried out in shared participation and inter-sectoral coordination with Ludhiana Police who helped with logistics as well as with providing volunteers for data collection. Study Participants: Participants included adults more than 18 years of age. Approximately every fifth person coming across the volunteers at the designated places, was observed for wearing the mask and thereafter interviewed using the predesigned semi-structured proforma. Care was taken to avoid repetition of study participants by enrolling persons moving in one direction only.

Sample size: The prevalence of mask usage is variable in different parts of country. Ludhiana city has a population of approximately $20,00,000$ therefore at $95 \%$ level of confidence and to have the estimate within a confidence interval of 1.5 , the sample size came out to be 4,259 . So we planned to interview 5000 persons from general population of Ludhiana city. The sample size was divided equally among 10 chosen sites and finally the study investigators were able to observe and interview 6995 participants. The sites were chosen in consultation with Police officials and included crowded public places, religious institutions, markets, bus stand, railway station etc. This physical on-site observation was also supplemented by observing the effective mask use pattern at the 10 selected crowded sites through CCTV. This was accomplished by observing the Closed-Circuit TV (CCTV) feeds of safe city control room of Punjab Police by the investigators.

Definition of Effective mask usage: A face mask properly covering mouth and nose was considered as effective mask usage.

Proforma: Proforma contained questionnaire about demographic information including age, gender, education, occupation, and ethnicity as well as questions about practice, perceptions and beliefs about correct mask usage. People with improper mask usage not covering nose and mouth were considered as ineffective mask usage. The proforma was translated in Hindi and Punjabi also for ease of understanding, and the filling was done by the interviewer after observing the participant for mask usage. The comprehensibility and reproducibility of the questionnaire was checked through a pilot study among 30 people from general public who were later not included in study participants.

\section{Data collection}

Direct observation: Volunteers were trained about scope of study, observation criteria as well as administration and filling of questionnaire by the investigators. The participants from general public were interviewed in the pre-selected areas on working days of a week for 3-4 hours in day time, by the trained volunteers on the basis of preformed semi-structured Proforma in their own vernacular language after taking informed consent. At each spot 4 volunteers were posted who were entrusted the task of observation, filling of proforma and health education. Participation in the study was totally voluntary and data collected was kept anonymous. After observing the participants for effective mask usage (EMU), data regarding demographic information, practices, perceptions and beliefs about mask usage were collected. Suggestions were also sought from participants for improving the compliance of proper mask usage. After 
direct observation and interviewing and filling the proforma, volunteers gave incentive to the good mask user in form of biscuits and fruits. Education about proper mask usage was also provided by the volunteers and investigators on the site.

Indirect observation: Indirect observation of EMU was done through CCTV feeds of safe city control room of Ludhiana Police for 2 hours a day by the trained volunteers, so as to observe the general public behavior regarding mask usage at the selected places. The initial observations were followed by intensive health education campaign at crowded places in Ludhiana city regarding proper mask usage, through pamphlets distribution, recorded loudspeaker messages and public health talks. Free face masks were also distributed to general public at the initiative of our institution and district administration. Indirect CCTV observations were again done in the same selected areas by the same volunteers to see any behavior change in general public regarding compliance of EMU after the health education campaign.

Statistical Analysis: Data collected was entered in Microsoft excel ${ }^{\circledR}$ worksheet by data entry operators and analyzed using Statistical Package for the Social Sciences (IBM SPSS Statistics for Windows, Version 20.0. Armonk, NY: IBM Corp.). Chi-square test was used to conduct univariate analysis to see association among the qualitative variables and EMU. A p-value of $<0.05$ was considered as statistically significant. Binary logistic regression was done to calculate adjusted odds ratio for any significant variables of EMU.

\section{Results}

A total of 6,995 participants were observed and interviewed for EMU in various areas of Ludhiana city. As is clear from the (Figure 1), though 5,418 participants (77.5\%) were observed to be wearing mask but EMU was seen in only 4,332 (61.9\%) participants.

Observations were done near religious places, residential areas, crowded roads \& intersections, near bus stand, railway station, hospitals and public places including markets, gardens, administrative offices, malls etc. and number of participants observed by the volunteers were ranging from 254 at railway station to 2,211 at roads and intersections as shown in (Table 1).

Maximum EMU was seen near roads and intersections (66.7\%), and minimum near hospitals (52.8\%). Maximum violation was seen near hospitals, railway station and busstand.

On comparing the demographic variables, mask usage in participants had no statistically significant difference on the basis of gender and place of residence, whereas EMU had significant association with age, ethnicity, education, and occupation. The participants in the age group 18-40 yrs. had significantly higher EMU than older age groups. Participants who had no formal education (46.9\%) or were below matric (58.9\%) had lesser EMU in this survey than those who were educated above matric (67.6\%). Native residents of this place showed higher EMU (62.8\%) than migrants (58.8\%) as shown in (Table 2 ).

Distribution of effective mask usage with respect to occupation is shown in (Figure 2). Drivers (69.8\%), service professionals (68.3\%) and students (68.3\%) had higher compliance to EMU whereas unemployed (49.8\%), daily wagers (59.8\%), housewives (57.8\%) had lower compliance to EMU and the difference was statistically significant.

The activity that the participants were doing at the time of observation was also noted and it was seen that the compliance of EMU was significantly higher in those driving two wheelers (76.8\%) and four wheelers (74.3\%) than those who were cycling $(65.9 \%)$, walking (56.1\%), travelling in a vehicle as a rider (65.7\%) or talking/walking in a group (50.3\%) as shown in (Table 3 ).

Binary logistic regression analysis was conducted to calculate the adjusted odds ratio to see any significant predictors of EMU in the study population. It was observed that younger age ( $<40 \mathrm{yrs}$ ), education (above matric) and occupation (driver, service \& student) had significant positive association with EMU while walking/ talking in a group as activity at the time of observation had a significant negative association with EMU (Table 4).

Participants not wearing mask or not wearing mask properly, were asked the reason for not doing so and 2,333 participants responded back and their responses were tabulated (Table 5). Most common cited reasons for non-compliance were breathing difficulty (32.7\%), feeling uncomfortable (25.3\%), no use of wearing mask (10.7\%) or not aware about importance of mask use (10.6\%). Cost of mask was also cited as reason for not wearing mask by 209 participants.

Approximately $70 \%$ of participants believed that mask use can prevent Covid-19 infection, whereas $16.3 \%$ were not sure and $14 \%$ responded in negative (Figure 3 ).

Responses of participants were also sought for the most effective preventive steps for preventing Covid-19 spread (Figure 4) and multiple responses were allowed. Proper mask usage $(75.4 \%)$, hand washing $(73.4 \%)$ and social distancing (59.6\%) were perceived as the most effective preventive methods by the participants.

As with the pandemic, infodemic is also spreading, participants were asked about their source of information about Covid-19. TV and newspapers (70.5\%), social media $(54.3 \%)$, friends and relatives (49.2\%) were the most common sources of information among the participants as shown in (Figure 5).

Other sources of information were public announcement and district administration, police personnel, health workers etc.

Indirect observation before and after intervention: As an additional measure to check the compliance to EMU, general public was also observed through CCTV footage of safe city control room of Punjab police at pre-selected 
crowded places and observations were merged into six categories for simplification as shown in (Table 6).

Overall EMU was $57.5 \%$, and was highest near public places $(65 \%)$, roads and intersections $(64.9 \%)$ and was lowest near bus stand (47.5\%) and religious places (49.4\%). Health education regarding effective mask usage was provided in these preselected areas by our team in collaboration with district administration, indirect observations were again made (through CCTV) which showed a little improvement among public at religious places ( $49.4 \%$ vs. $52.8 \%)$, near bus stand ( $47.5 \%$ vs. $49.3 \%$ ) and railway station $(60.8 \%$ vs. $62.8 \%)$, whereas it was lower at market places ( $51.3 \%$ vs. $46.6 \%$ ) and public places (65\% vs. $63.9 \%$ ) than earlier observation as shown in (Table 6).

\section{Discussion}

Novel Corona virus or SARS-CoV-2 infection was first identified in Wuhan, China and it was declared Global Health emergency on $30^{\text {th }}$ January,2020, and Global pandemic on $11^{\text {th }}$ March,2020 by WHO. It spreads by droplets and aerosols which remain viable in the air for several hours and it has been observed that such aerosols can be blocked by proper mask usage in experimental settings.(10) The infectivity period of infected individuals starts from approximately 2-3 days before they become symptomatic.(11) It has been estimated that about $50 \%$ of infections can be transmitted from these presymptomatic individuals unknown to the infected person and new contact.(12) That is why mask usage along with handwashing, physical distancing are important for everyone to prevent getting infection from presymptomatic as well as symptomatic infected persons.(13) In an experimental modelling setup, it was shown that mask usage by $80-90 \%$ of population is one of the most effective interventions and can result in less stringent lockdown requirements.(14) Leading health regulatory bodies such as World Health Organization (WHO) and Centre for Disease Control (CDC) have repeatedly emphasized the importance of mask usage, social distancing, and hand hygiene among other measures for prevention of spread of COVID-19.(15)

Countries have implemented various measures such as audiovisual or text messages, posters to encourage people to wear masks whereas some countries have also been imposing fines for not wearing masks in public.(16) Though it is difficult to pinpoint the cause of resurgence of cases, yet festive season, opening up of public places, onset of winter and laxity on part of people about adherence to preventive measures, possibly due to pandemic fatigue, are cited as the probable cause of spread of infection by experts.(17)

It is very important to study public behavior and mask usage pattern of general public to look into their practice, perceptions and barriers to effective mask usage so that necessary policy changes and interventions can be made at public health level. In our study EMU was seen in nearly $62 \%$ participants, which is well below the target. It was also observed that among those wearing mask, in $20 \%$ participants mask usage was improper i.e. not covering nose and mouth. This reflects that not only general public need to be educated about mask usage but also about its effective use. Maximum EMU was seen near roads and intersections and in those driving two wheelers and four wheelers. This may be due to the fact that there is constant vigilance on the roads and intersections by the police personnel and sometimes fines are also levied on the public. Younger Age, education above matric and native population had significantly higher adherence to effective mask usage. Probably elderly participants, lower education level, daily wage workers, unemployed and migrant population have had less exposure to health education, so these could form our target groups for further dissemination of knowledge. Similar observation was made in a study in which younger population had higher knowledge scores as compared to those between 50 to 60 years and those between $60-70$ years.(18) In another study it was found that wearing of face masks is associated with gender, age group, region and occupation.(19) Lesser knowledge among elderly population should be targeted in health education about Covid-19 as the elderly people with co-morbidities are more likely to suffer from moderate to severe form of disease.(20) Most (70\%) of participants in present study had a positive attitude and believed that mask usage could prevent Covid-19 spread, yet the compliance of mask usage among participants was low revealing a knowledgepractice gap. In another study, though most of the participants were aware about proper mask wearing $(78 \%)$ and avoiding touching the mask $(42.3 \%)$ as important measures for prevention, still only one-fifth (20\%) used facemask in public.(18)

In our study, commonly cited reasons by the participants for not wearing mask properly or no mask at all, were breathing difficulty, mask being uncomfortable among other reasons. Public needs to be assured that mask usage may cause little discomfort for a short time but its benefits are manifold. Though many researchers disagree on the amount of transmissibility reduction with mask use, yet everyone agrees that modest benefits collectively can be highly beneficial due to the exponential character of the transmission process.(21) TV and newspapers, social media, friends and relatives were cited as the most common sources of information regarding prevention of COVID-19 which could be due to increased viewing of television, internet, social media during and after lockdown by general public.(22)

Indirect observation of mask use through screening CCTV footage from selected locations in the city showed that overall EMU was 57.5\%, with highest being near public places, roads and intersections and lowest near bus stand and religious places. An intensive public health education 
campaign was run by investigators, faculty $\&$ interns from our institute and volunteers from Punjab police through audiovisual messages, poster distribution, public meetings etc. along with distribution of mask and educating people about proper mask usage. Post intervention compliance was variable being higher at religious places, near bus stand and railway station, whereas it was lower at marketplaces and public places. Marketplaces saw a decline in compliance $(51.3 \%$ to $46.6 \%$ ) possibly because of the festival season and people shedding all inhibitions regarding Covid-19. Also, a fatigue could have set in the public regarding adherence to Covid prevention guidelines because of prolonged pandemic.

We can observe from above findings that overall compliance in general public is low and much is needed to be done and there is no place for complacency. Though vaccination drive kicked in country in January, experts opine that even after vaccination, preventive steps including mask wearing remains of paramount importance in control of this disease as vaccinated persons could have mild illness, or could be carriers also. Mask wearing especially becomes important in the wake of emergence of new highly infectious strains of Corona virus one of which is called B.1.1.7 variant (Alpha virus) which has 17 mutations and it had been reported that out of the samples sent by the Punjab government for genome sequencing, $81 \%$ have tested positive for this variant.(23) Other of SARS-CoV-2 variants are B.1.351(Beta), P.1 (Gamma) and B.1.617.2 (Delta) which have high virulence. This is a cause of worry and only effective strategy is to observe COVID appropriate behavior including mask wearing, social distancing and hand hygiene.(24)

\section{Conclusion}

Compliance to mask usage was lower in some specific groups such as elderly, migrants, unemployed, daily wage worker etc. so they should be specifically targeted for health education. It was also observed that EMU was lower at religious places and market places, so religious and local leaders should be involved in effective dissemination of the health education messages. Behavior change is difficult but well-planned interventions can help us in bringing change in public behavior. Findings of the study were shared with the district administration and public education drive was intensified.

\section{Limitation of the study}

This survey could observe the compliance to EMU of a participant at the time of observation only and does not completely tell about his/her mask usage behavior at other times. Another limitation is that while doing indirect observation using CCTV, same population could not be observed in the pre and post intervention observations.

\section{Authors Contribution}

All authors contributed equally.

\section{Acknowledgement}

Authors are thankful to faculty from departments of Anatomy and Pharmacology, DMCH for participating in health education campaign and to Mrs. Bectors Food Specialties Ltd. for providing with biscuits for distribution among general public during the campaign.

\section{References}

1. WHO Corona virus (Covid-19) dashboard. Available at: https://covid19.who.int/ . Accessed 25th June, 2021.

2. WHO Corona virus (Covid-19) dashboard available at https://covid19.who.int/region/searo/country/in . Accessed 25th June, 2021.

3. Weekly Update: Global Coronavirus Impact and Implications. Available at: https://www.counterpointresearch.com/coronavirusweekly-update/ Accessed 25th June, 2021.

4. Coronavirus Second Wave? Why Cases Increase? Available at: https://www.hopkinsmedicine.org/health/conditions-anddiseases/coronavirus/first-and-second-waves-of-coronavirus Accessed 25th June, 2021.

5. COVID-19 mutant more infectious, responsible for second wave of pandemic: Study. Available at https://www.businesstoday.in/current/world/covid-19-mutantmore-infectious-responsible-for-second-wave-of-pandemicstudy/story/422058.html . Accessed 25th June, 2021.

6. Daily New Cases in India. Available at: https://www.worldometers.info/coronavirus/country/india/ Accessed 25th June, 2021.

7. COVID-19 second wave: Maharashtra, Punjab reporting highest daily cases and deaths, say data. Available at: https://www.newindianexpress.com/nation/2021/apr/04/covid19-second-wave-maharashtra-punjab-reporting-highest-dailycases-and-deaths-say-data-2285658.html . Accessed 25th June, 2021.

8. Punjab's case fatality rate higher \& recovery rate lower than national and Maharashtra figures. Available at: https://indianexpress.com/article/cities/chandigarh/punjabscase-fatality-rate-higher-recovery-rate-lower-nationalmaharashtra-7242497/ Accessed 25th June, 2021.

9. Corona India Tracker. Punjab. Available at: https://coronaclusters.in/punjab . Accessed 25th June, 2021.

10. Leung NHL, Chu DKW, Shiu EYC et al. Respiratory virus shedding in exhaled breath and efficacy of face masks. Nat Med 2020; 26: 67680.

11. Ferretti L, Wymant C, Kendall M, Zhao L, Nurtay A et al. Quantifying SARS-CoV-2 transmission suggests epidemic control with digital contact tracing. Science 2020:368(6491):eabb6936. Doi 10.1126/science.abb6936

12. Ganyani T, Kremer C, Chen D, et al. Estimating the generation interval for coronavirus disease (COVID-19) based on symptom onset data. Euro Surveill. 2020;25(17):2000257. doi:10.2807/15607917.ES.2020.25.17.2000257

13. Gandhi, M., Beyrer, C. \&Goosby, E. Masks Do More Than Protect Others During COVID-19: Reducing the Inoculum of SARS-CoV-2 to Protect the Wearer. J Gen Intern Med. 2020; 35(10): 3063-66. https://doi.org/10.1007/s11606-020-06067-8

14. Stutt R, Retkute R, Bradley M, Gilligan CA, Colvin J. A modelling framework to assess the likely effectiveness of facemasks in combination with 'lock-down' in managing the COVID-19 pandemic. Proc. R. Soc. A2020, 476: 20200376 https://doi.org/10.1098/rspa.2020.0376

15. World Health Organization. Coronavirus disease (COVID-19) advice for the public: When and how to use masks. Available at: https://www.who.int/emergencies/diseases/novel-coronavirus2019/advice-for-public/when-and-how-to-use-masks Accessed 25th June, 2021.

16. Which countries have made wearing face masks compulsory? Al Jazeera News. Available at: 
https://www.aljazeera.com/news/2020/04/countries-wearingface-masks-compulsory-200423094510867.html . Accessed 25th June, 2021.

17. Delhi reels under second wave of coronavirus as cases jump. Available at: https://www.deccanchronicle.com/nation/currentaffairs/291020/delhi-reels-under-second-wave-of-coronavirus-ascases-jump.html . Accessed 25th June, 2021.

18. Kadir Alam, SubishPalaian, Pathiyil Ravi Shankar, Nisha Jha. General public's knowledge and practices on facemask use during the COVID-19 pandemic: a cross-sectional exploratory survey from Dharan, Nepal. Available at: https://www.researchsquare.com/article/rs-42148/v1 . Accessed 25th June, 2021.

19. Azlan AA, Hamzah MR, Sern TJ, Ayub SH, Mohamad E. Public knowledge, attitudes and practices towards COVID-19: A crosssectional study in Malaysia. PLOS ONE. 2020. 15(5): e0233668. Available at: https://doi.org/10.1371/journal.pone.0233668.
20 patients: a comparison with young and middle-aged patients. J Infect. 2020;80(6):e14-e18. doi: 10.1016/j.jinf.2020.03.005 .

21. Howard J, Huang A, Li Z, Tufekci Z, Zdimal V, van der Westhuizen H et al. Face Masks Against COVID-19: An Evidence Review. Preprints 2020, 2020040203 (doi: 10.20944/preprints 202004.0203.v1).

22. González-Padilla DA, Tortolero-Blanco L. Social media influence in the COVID-19 Pandemic. Int Braz J Urol. 2020 ;46(1):120-124.

23. $81 \%$ of Punjab's New COVID-19 Cases Are Due to Strain Spotted in UK: CM. Available at: https://science.thewire.in/health/81-ofpunjabs-new-covid-19-cases-are-due-to-strain-that-originated-inuk-cm/. Accessed 25th June, 2021.

24. CDC. Science Brief: Emerging SARS-CoV-2 Variants. Available at: https://www.cdc.gov/coronavirus/2019-ncov/science/sciencebriefs/scientific-brief-emerging-variants.html. Accessed 25th June, 2021.

\section{Tables}

\section{TABLE 1MASK USE PATTERN WITH RESPECT TO PLACE OF OBSERVATION BY DIRECT OBSERVATION}

\begin{tabular}{|cccccc|}
\hline Place of Observation & Total & \multicolumn{2}{c|}{ Mask Use } & \multicolumn{2}{c|}{ Effective Mask Use } \\
\hline & & NO (\%) & YES (\%) & No (\%) & YES (\%) \\
\hline Religious Places & 553 & $131(23.6)$ & $422(76.4)$ & $240(43.4)$ & $313(56.6)$ \\
\hline Residential Areas & 1028 & $243(23.7)$ & $785(76.3)$ & $398(38.7)$ & $630(61.3)$ \\
\hline Roads \& Intersections & 2211 & $432(19.5)$ & $1779(80.5)$ & $737(33.3)$ & $1474(66.7)$ \\
\hline Bus Stand & 322 & $82(25.5)$ & $240(74.5)$ & $147(45.6)$ & $175(54.3)$ \\
\hline Railway Station & 254 & $63(24.8)$ & $191(75.2)$ & $115(45.3)$ & $139(54.7)$ \\
\hline Public places & 1879 & $431(22.9)$ & $1448(77.1)$ & $673(35.8)$ & $1206(64.2)$ \\
\hline Hospitals & 748 & $195(26.1)$ & $553(73.9)$ & $353(47.2)$ & $395(52.8)$ \\
\hline TOTAL & 6995 & $1577(22.5)$ & $5418(77.5)$ & $2663(38.1)$ & $4332(61.9)$ \\
\hline
\end{tabular}

\begin{tabular}{|c|c|c|c|c|c|c|}
\hline & \multirow[t]{2}{*}{ Variable (n) } & \multicolumn{2}{|c|}{ Effective Mask Use } & \multirow{2}{*}{$\begin{array}{c}\text { Chi square } \\
0.539\end{array}$} & \multirow{2}{*}{$\begin{array}{c}\text { OR }(95 \% \mathrm{Cl}) \\
1.050(0.921-1.197)\end{array}$} & \multirow{2}{*}{$\begin{array}{c}\text { P value } \\
0.485 \text { (NS) }\end{array}$} \\
\hline & & Yes (\%) & No (\%) & & & \\
\hline \multirow[t]{2}{*}{ Sex } & Male (5847) & 3610 (61.7) & $2237(38.3)$ & & & \\
\hline & Female (1148) & 722 (62.9) & $426(37.1)$ & & & \\
\hline \multirow[t]{3}{*}{ Age (Yrs) } & $18-40(4706)$ & 3006 (63.9) & $1700(36.1)$ & \multirow[t]{3}{*}{23.102} & \multirow[t]{3}{*}{ NA } & \multirow[t]{3}{*}{$<0.001$ (HS) } \\
\hline & $41-60$ (1974) & 1143 (57.9) & 831 (42.1) & & & \\
\hline & $>61(315)$ & $183(58.1)$ & 132 (41.9) & & & \\
\hline \multirow[t]{3}{*}{ Education } & Illiterate (971) & 455 (46.9) & $516(53.1)$ & \multirow[t]{3}{*}{154.55} & \multirow[t]{3}{*}{ NA } & \multirow[t]{3}{*}{$<0.001(\mathrm{HS})$} \\
\hline & Below Matric (2246) & 1322 (58.9) & 924 (41.1) & & & \\
\hline & Above Matric (3778) & 2555 (67.6) & $1223(32.4)$ & & & \\
\hline \multirow[t]{2}{*}{ Ethnicity } & Native (5524) & 3467 (62.8) & 2057 (37.2) & \multirow[t]{2}{*}{7.72} & \multirow[t]{2}{*}{$0.847(0.753-0.952)$} & \multirow[t]{2}{*}{0.006 (HS) } \\
\hline & Migrant (1471) & $865(58.8)$ & $606(41.2)$ & & & \\
\hline \multirow[t]{2}{*}{ Residence } & Urban (5278) & 3301 (62.5) & 1977 (37.5) & \multirow[t]{2}{*}{3.423} & \multirow[t]{2}{*}{$0.90(0.805-1.006)$} & \multirow[t]{2}{*}{0.067 (NS) } \\
\hline & Rural (1717) & $1031(60)$ & $686(40)$ & & & \\
\hline
\end{tabular}

TABLE 3 EFFECTIVE MASK USE WITH RESPECT TO ACTIVITY AT THE TIME OF OBSERVATION

\begin{tabular}{|c|c|c|c|c|}
\hline \multirow[t]{2}{*}{ Activity (n) } & \multicolumn{2}{|c|}{ Effective Mask Use } & \multirow[t]{2}{*}{ Chi square } & \multirow[t]{2}{*}{ P value } \\
\hline & Yes (\%) & No (\%) & & \\
\hline Driving two wheeler (1408) & $1082(76.8)$ & $326(23.2)$ & \multirow[t]{8}{*}{342.33} & \multirow[t]{8}{*}{$<0.001(\mathrm{HS})$} \\
\hline Driving four wheeler (746) & $554(74.3)$ & $192(25.7)$ & & \\
\hline Cycling (838) & $552(65.9)$ & $286(34.1)$ & & \\
\hline Travelling in a vehicle (315) & $207(65.7)$ & $108(34.3)$ & & \\
\hline Walking (1607) & $901(56.1)$ & 706 (43.9) & & \\
\hline Talking or walking in a group (1170) & $588(50.3)$ & $582(49.7)$ & & \\
\hline Sitting quietly/ Any other (911) & $448(49.2)$ & $463(50.8)$ & & \\
\hline Total (6995) & 4332 (61.9) & $2663(38.1)$ & & \\
\hline
\end{tabular}




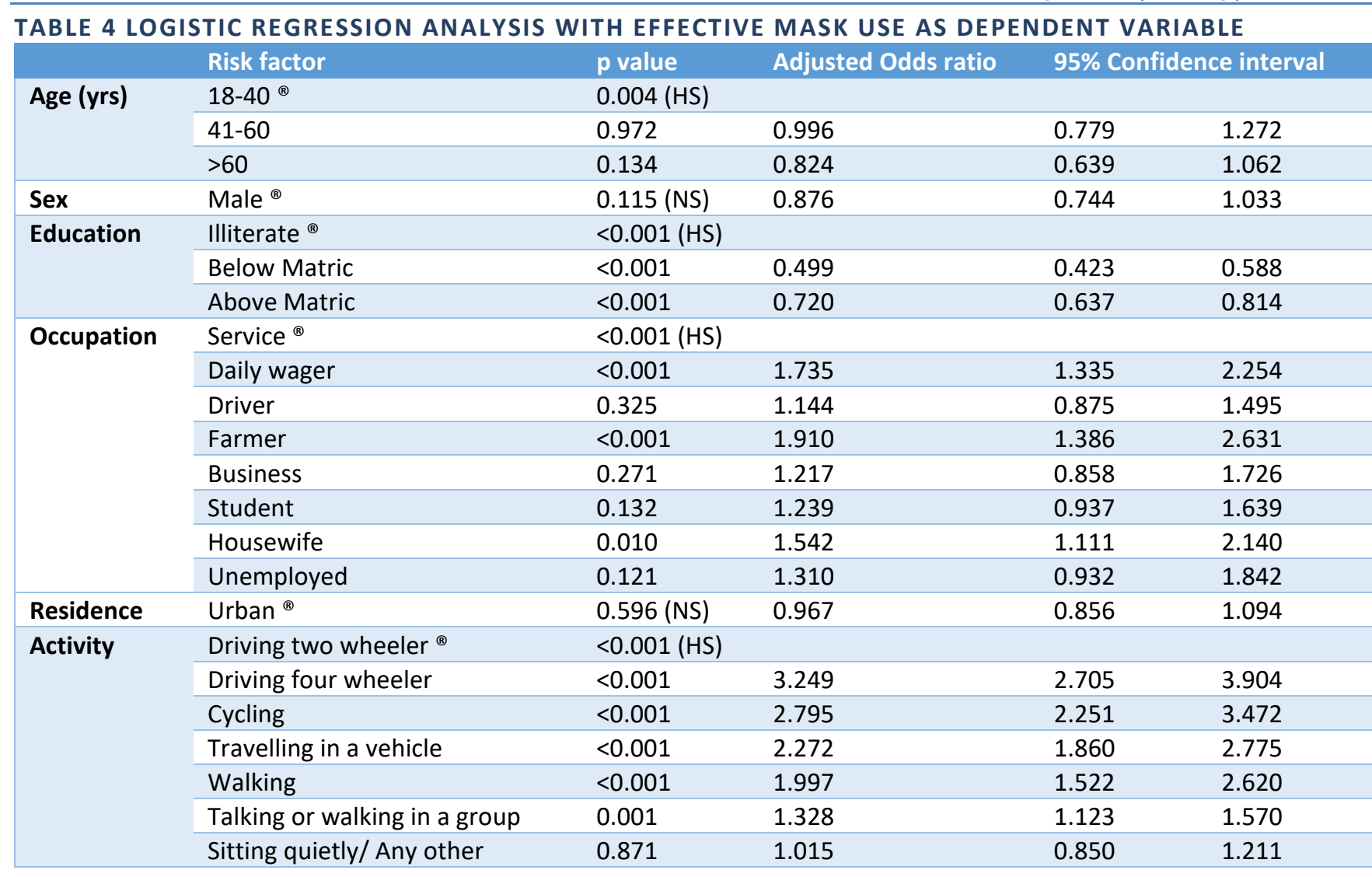

\section{TABLE 5 REASONS FOR NOT WEARING MASK ( $\mathrm{N}=2663)$}

\begin{tabular}{|ccc|}
\hline Reason & Number & Percentage \\
\hline Cost of mask & 209 & 7.8 \\
\hline Uncomfortable & 673 & 25.3 \\
\hline Causes breathing difficulty & 870 & 32.7 \\
\hline No use of wearing mask & 285 & 10.7 \\
\hline Not aware about its use & 282 & 10.6 \\
\hline Any Other & 14 & 0.5 \\
\hline No response & 330 & 12.4 \\
\hline
\end{tabular}

\begin{tabular}{|c|c|c|c|c|c|c|}
\hline \multirow[t]{2}{*}{ Place of Observation } & \multirow[t]{2}{*}{$\begin{array}{c}\text { Total } \\
\text { Observations }\end{array}$} & \multicolumn{2}{|c|}{$\begin{array}{c}\text { Pre- intervention Effective Mask } \\
\text { Use }\end{array}$} & \multirow[t]{2}{*}{$\begin{array}{c}\text { Total } \\
\text { Observations }\end{array}$} & \multicolumn{2}{|c|}{$\begin{array}{l}\text { Post- intervention } \\
\text { Effective Mask Use }\end{array}$} \\
\hline & & No (\%) & Yes (\%) & & No (\%) & Yes (\%) \\
\hline Religious places & 703 & $356(50.6)$ & $347(49.4)$ & 543 & $256(47.1)$ & $287(52.8)$ \\
\hline $\begin{array}{l}\text { Roads and } \\
\text { intersections }\end{array}$ & 1144 & $401(35.1)$ & $743(64.9)$ & 1421 & $497(35.0)$ & $924(65.0)$ \\
\hline Market places & 1215 & $592(48.7)$ & $623(51.3)$ & 1276 & $681(53.4)$ & $595(46.6)$ \\
\hline Near Bus stand & 217 & $114(52.5)$ & $103(47.5)$ & 698 & $354(50.7)$ & $344(49.3)$ \\
\hline Near Railway station & 189 & $74(39.2)$ & $115(60.8)$ & 285 & $106(37.2)$ & $179(62.8)$ \\
\hline Other public places & 838 & $293(35.0)$ & $545(65.0)$ & 842 & $304(36.1)$ & $538(63.9)$ \\
\hline Total & 4306 & $1830(42.5)$ & $2476(57.5)$ & 5065 & 2198(43.4) & $2867(56.6)$ \\
\hline
\end{tabular}




\section{Figures}

FIGURE 1: DISTRIBUTION OF PARTICIPANTS WITH RESPECT TO A-MASK USAGE, B-EFFECTIVE MASK USAGE

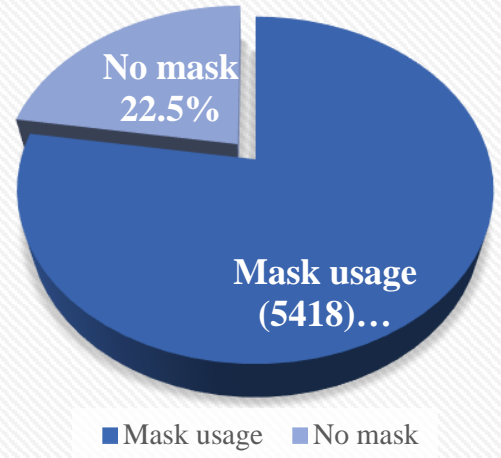

FIGURE 2: EFFECTIVE MASK USE AS PER OCCUPATION OF PARTICIPANTS

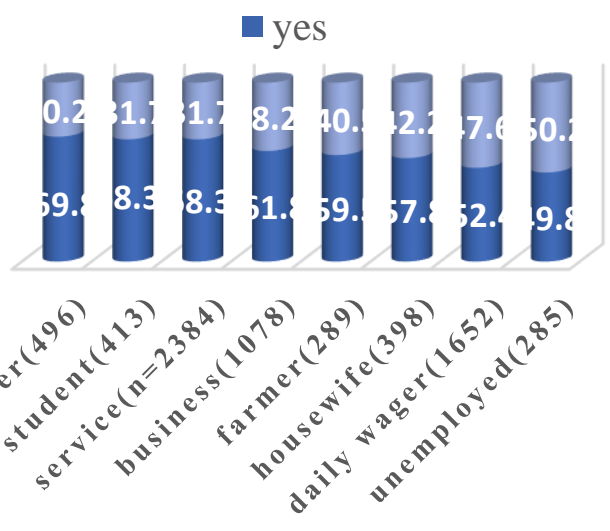

FIGURE 3: RESPONSE OF PARTICIPANTS ABOUT THEIR PERCEPTIONS IF MASK USE CAN PREVENT COVID-19 SPREAD

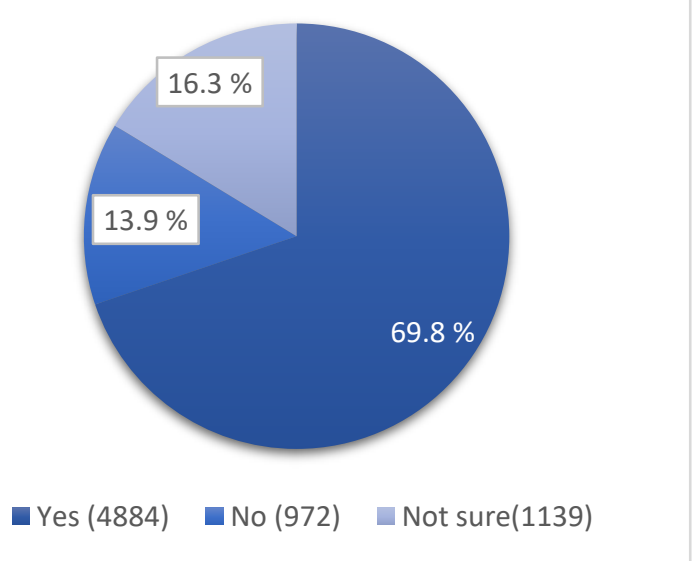

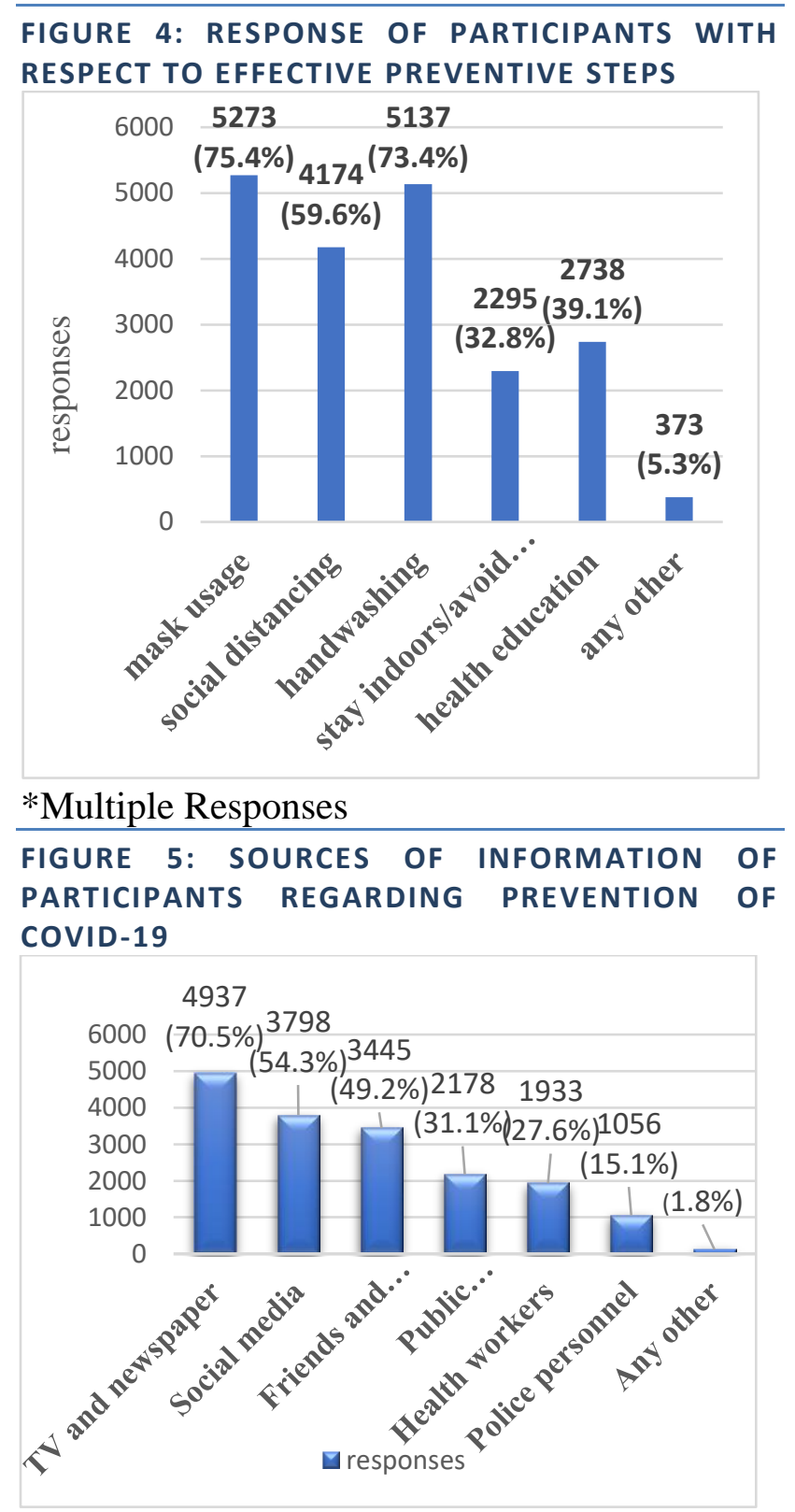

